University of Nebraska - Lincoln DigitalCommons@University of Nebraska - Lincoln

Public Health Resources

Public Health Resources

1998

\title{
Age-dependent characteristics of protection v. susceptibility to Plasmodium falciparum
}

J. Kevin Baird

ALERTAsia Foundation, jkevinbaird@yahoo.com

Follow this and additional works at: http://digitalcommons.unl.edu/publichealthresources

Baird, J. Kevin, "Age-dependent characteristics of protection v. susceptibility to Plasmodium falciparum" (1998). Public Health Resources. 418.

http://digitalcommons.unl.edu/publichealthresources/418

This Article is brought to you for free and open access by the Public Health Resources at DigitalCommons@University of Nebraska - Lincoln. It has been accepted for inclusion in Public Health Resources by an authorized administrator of DigitalCommons@University of Nebraska - Lincoln. 


\title{
Age-dependent characteristics of protection $v$. susceptibility to Plasmodium falciparum
}

\author{
BY J. K. BAIRD* \\ Malaria Program, Naval Medical Research Institute, 12300 Washington Avenue, Rockville, \\ MD 20852, U.S.A.
}

Received and accepted 6 November 1997

Naturally acquired immunity to Plasmodium falciparum may be linked to key features of the immune system that change during normal development and ageing. Evidence of this was seen in non-immune Javanese transmigrants taking up residence in hyperendemic Irian Jaya, Indonesia. After 1-2 years of residence, the adult migrants had less frequent and less intense parasitaemias than their children. Splenomegaly and malaria-like symptoms were also less common in the adults. These age-dependent patterns of relative resistance to $P$. falciparum mirrored those in lifelong residents. The Javanese adults acquired protective immunity against chronic exposure to infection relatively quickly compared with their children. However, during the initial exposure to infection, the incidence of emergency medical evacuation to hospital with a clinical diagnosis of malaria was 7 -fold higher among the adults than in their children. The exaggerated susceptibility of adults to severe morbidity and mortality has been reported in other populations during initial exposure to infection. Thus, whereas adults acquired protection against chronic exposure more rapidly than the children, they were initially more susceptible to severe disease. One possible explanation for these findings is the changes in the immune system that normally occur during ageing. Such changes may establish differences between children and adults that profoundly affect the course of infection by $P$. falciparum. The ratio of naive to memory $T$ cells gradually diminishes during ageing, as a result of the cumulative effect of exposure to the myriad antigens encountered throughout the normal course of life. Moreover, the gradual involution of the thymus progressively limits the production of naive $T$ cells. The likelihood of stimulating memory $T$ cells with cross-reactive antigens may increase with age and this may bias the immune response to the relative benefit of the host under chronic exposure, or to the detriment of the host under acute exposure. Intrinsic features of the immune system that change with age may determine key characteristics of the immune response to infection by $P$. falciparum, and whether that response is relatively harmful or beneficial may depend upon the conditions of exposure (i.e. acute or chronic).

Attempts to explain the apparently slow development of naturally acquired immunity against Plasmodium falciparum have long focused upon antigenic polymorphism and variation in the parasite. Few studies have assessed the possible effects of changes in the immune system that occur during normal development and ageing in the host. Is the pronounced resistance to infection seen in adults living under hyper- or holo-endemic malaria the cumulative product of lifelong heavy exposure to antigen, or is it the product

*E-mail: bairdk@nmripo.nmri.nnmc.navy.mil; fax: + 1 3012956171. of only recent exposure and intrinsic features of their immune systems that distinguish them from children?

Naturally acquired immunity has been considered a poor model for vaccination. That position stems from the notion that protection apparently requires $10-15$ dangerous years of exposure to the parasite's full range of antigenic polymorphism and variation. The lack of a sterilizing protection further discouraged study of natural immunity as a model for vaccine development. What if natural immunity against heterologous parasites developed relatively quickly? If so, the induction of an adult-like natural immunity in children 
exposed to heavy infection pressure may seem both feasible and desirable; feasible because of the relatively low number and short duration of vaccinations required, and desirable because it should maintain natural immunity in the face, presumably, of a largely uninterrupted exposure to infection. Such a vaccine would radically curb the morbidity and mortality of holo-endemic malaria, without subsequent risk of epidemic malaria because of a conceivably short-lived interruption of transmission. However, such a vaccine is highly unlikely if natural immunity indeed requires many years of experience to 'learn' the antigenic repertoire of $P$. falciparum adequately.

This review presents an alternative explanation for the seemingly slow onset of naturally acquired immunity in endemic areas. Formulation of the hypothesis discussed stemmed from observations of non-immune young families from largely non-endemic Java who were taking up residence in hyper- to holo-endemic Irian Jaya in Indonesia. Agespecific patterns of parasitaemia and disease in these people during the acute and chronic phases of exposure to infection indicated that the intrinsic features of the immune system that change with age, together with exposure being acute or chronic, determined the relative degree of resistance or susceptibility to $P$. falciparum in each subject. If this hypothesis is true, the relatively rapid induction of adult-like natural immunity in chronically exposed children may represent a reasonable technical objective.

THE RELATIVE SUSCEPTIBILITY OF CHILDREN WITH HEAVY EXPOSURE

Infection by $P$. falciparum usually causes disease in non-immune humans of any age. In contrast, adults in hyper- or holo-endemic areas are routinely infected with this parasite but rarely ill. Children in these areas also have protection from death relative to people without a history of chronic heavy exposure. In northern Ghana, for example, multiple episodes of infection (i.e. approximately two to 10 episodes/person-year) caused death in
$<5 \%$ of children aged $\leq 7$ years (Binka et al., $1994,1995)$. Without acquired immunity, the mortality rate in these children would have been much greater. The devastating impact of $P$. falciparum on people without acquired immunity was demonstrated during some early European expeditions into tropical Africa. On one expedition to the Niger in $1842,40(28 \%)$ of 145 Caucasians died of malaria, as recounted by McGregor (1993). Among French troops in Senegal between 1819 and 1831, annual mortality ranged from $9.4 \%-57 \%$ of total troop strength (Curtin, 1994). Natural immunity in African children may be highly effective in preventing death, but less so compared with adults in the same area.

Despite relatively good protection against death, children in holo-endemic areas suffer extraordinarily high rates of morbidity because of the sheer burden of infection pressure. In the holo-endemic Sahel of northern Ghana, for example, $25 \%$ of children aged 6-24 months had severe anaemia at the end of the malaria season whereas $<2 \%$ were severely anaemic at the end of the low transmission season (K. Koram, unpubl. obs.). Severe anaemia corresponds with the high-density parasitaemias of early childhood (Fig. 1), whereas cerebral malaria in these populations tends to occur most often in slightly older children. The apparent protection of hyperparasitaemic young children from cerebral malaria has been attributed to a poorly defined process that is often called antitoxic immunity. Whether disease arises from anaemia or cerebral malaria, children seem ill-equipped to control blood-stage parasitaemia compared with their parents.

\section{THE CUMULATIVE-EXPOSURE HYPOTHESIS}

The relative susceptibility of children to blood-stage parasites is often attributed to an inadequate repertoire of memory and effector cells relative to the antigenic repertoire of parasites in the wild. The parasite presumably evades an effective immune response until the 


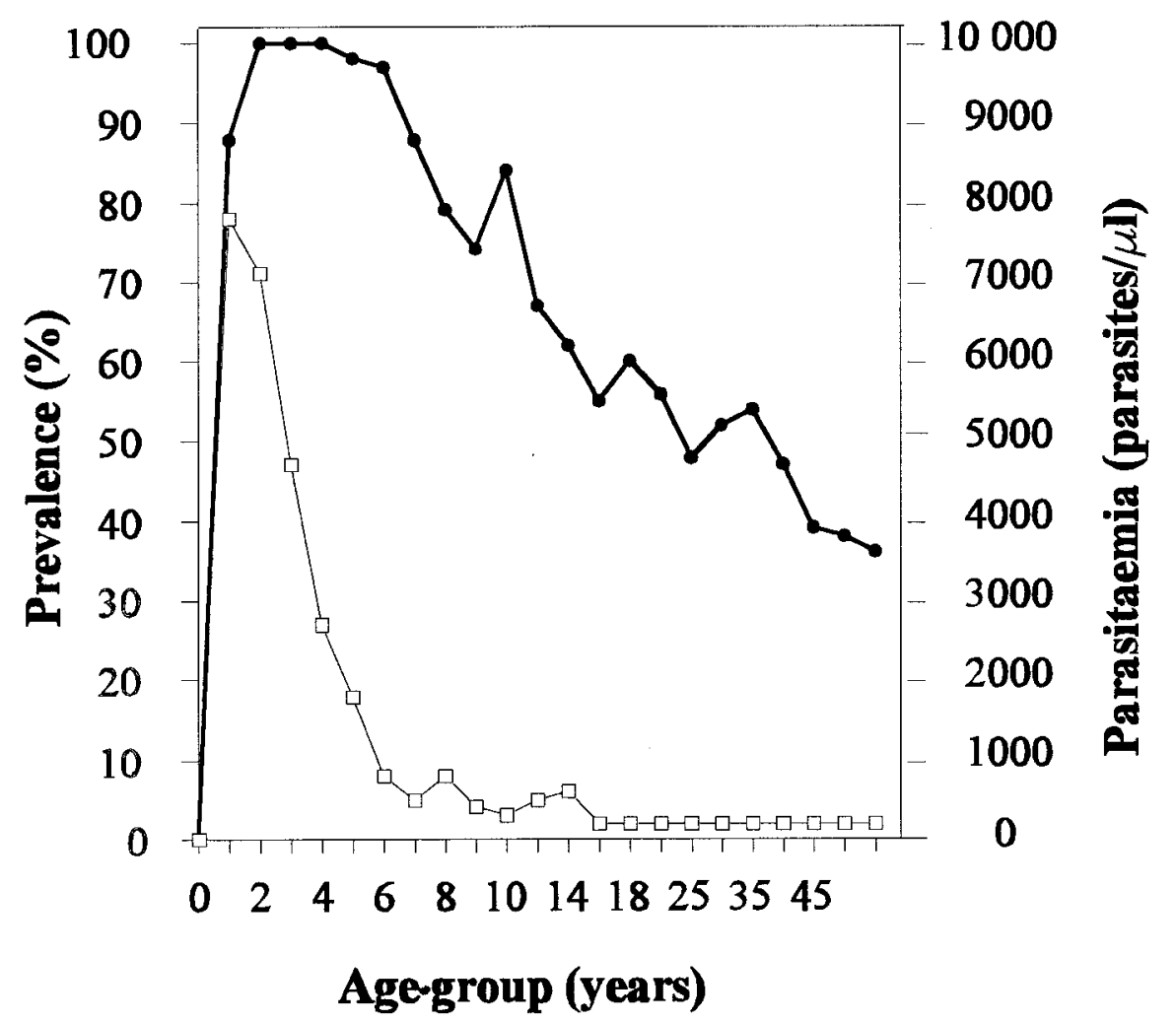

Fig. 1. Age-specific prevalence of $P$. falciparum parasitaemia $(\bullet)$ and mean intensity of the parasitaemia $(\square)$ in a holo-endemic village in eastern Africa, as reported by Wilson (1936).

host has experienced enough exposure to infection to mount an effective defence. On the basis of observations typified by those shown in Fig. 1, a period of 10-15 years of uninterrupted exposure to hyper- or holoendemic malaria has been considered sufficient for protection. This hypothesis was first proposed by Robert Koch (Koch, 1900a, $b, c, d)$ after he observed distinct age-specific patterns of parasitaemia between populations on Java exposed to hypo-endemic $v$. holoendemic malaria. The absence of an agerelated pattern among the relatively lightly exposed subjects inferred a requirement for heavy, uninterrupted exposure for protection. Indeed, parasitaemia tends to be uniform among age-groups or skewed to reflect restricted exposure to biting anophelines in areas where malaria is epidemic or hypo- or mesoendemic (Wernsdorfer and Wernsdorfer, 1988; Lepers et al., 1990; Razanamparany et al., 1995; Baird et al., 1996). Koch's contemporaries accepted that chronic exposure to hyper- or holo-endemic malaria was required for effective natural immunity. Gill (1914) explained, 'Finally, there is the fact that immunity becomes decreased or lost by residence in non-endemic areas. The conclusion therefore is irresistible, that repeated reinfection is an important factor in the production and maintenance of malarial immunity.'

For almost 30 years, beginning in the $1920 \mathrm{~s}$, malaria therapy of neurosyphilis allowed quantitative analysis of immunity to malaria. A solid, albeit non-sterilizing, immunity to $P$. falciparum developed rapidly in 


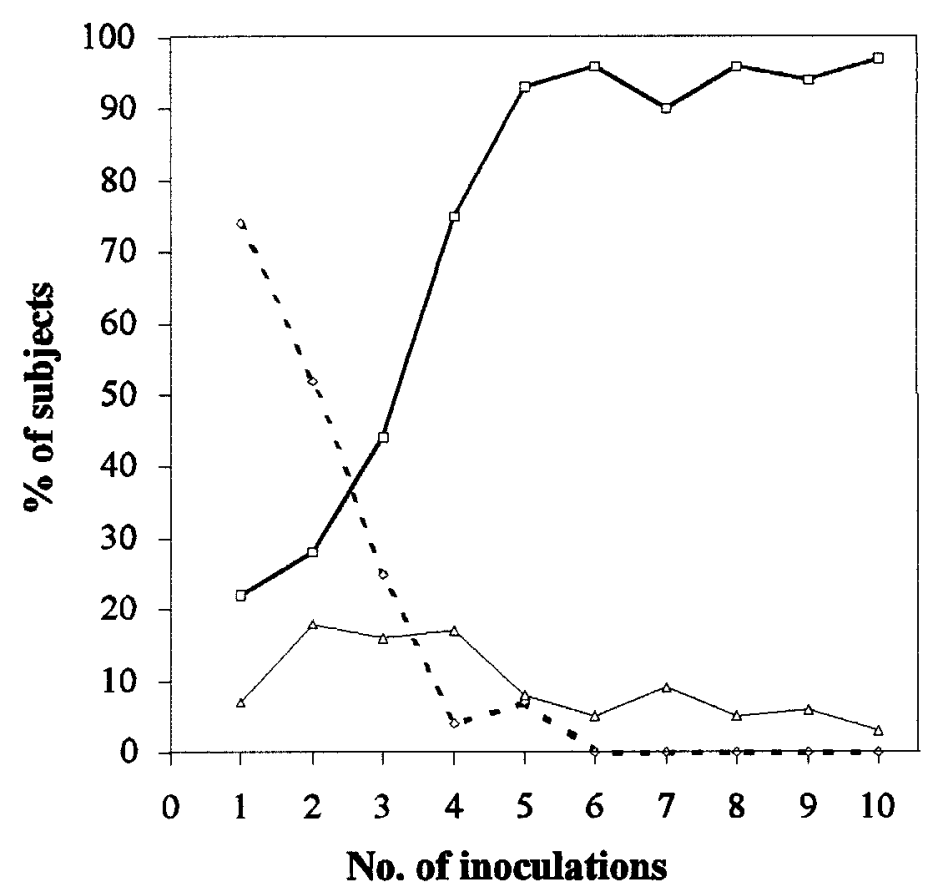

Fig. 2. Acquisition of immunity following successive exposures to infection. The prevalences of fever with parasitaemia $(\bigcirc)$, parasitaemia without fever $(\triangle)$ and neither fever nor parasitaemia $(\square)$ among 1066 neurosyphilis patients treated, with inoculations of Plasmodium falciparum at the Socola Malariatherapy Centre in Jassy, Romania (Ciuca et al., 1934).

most patients (i.e. after four to six infections; Fig. 2). The relatively rapid onset of protective immunity in these patients was attributed to the use of homologous strains of $P$. falciparum. Conversely, the slow onset of immunity in endemic populations was attributed to heterologous challenge (i.e. antigenic polymorphism). Immunity improved during childhood and through adult life, supposedly by the slow accumulation of strain-specific immunity to increasing numbers of individual strains. The demonstration of clonal antigenic variation in $P$. knowlesi (Brown and Brown, 1965) and $P$. falciparum (Hommel et al., 1983) reinforced this hypothesis. Extensive allelic polymorphism in $P$. falciparum (McBride et al., 1982) gave further credence to the hypothetical relationship between antigenic polymorphism and the slow onset of immunity. Studies have shown that serum-agglutinizing crossreactivity among $P$. falciparum strains is either low or monospecific in children, whereas adults from endemic areas tend to have much broader agglutinizing specificities (Marsh and Howard, 1985; Aguiar et al., 1992; Newbold et al., 1992). The slow acquisition of natural immunity has been viewed as the cumulative product of heavy exposure to infection, leading to acquisition of a repertoire of memory cells that effectively regulate effector function in suppressing the density of parasitaemia. In other words, natural immunity was hypothesised to be the sum of strain-specific immunities garnered over at least 10 years of exposure to hyper- or holo-endemic malaria.

\section{THE AGE-DEPENDENT HYPOTHESIS}

\section{Definition}

An alternative explanation for the slow onset of natural immunity is that the intrinsic changes in immune functions that affect the 
course of $P$. falciparum may be linked to normal host development and maturation. These changes may influence immunity to $P$. falciparum independent of the cumulative effects of uninterrupted exposure to infection. If normal development and maturation causes increasing resistance to malaria in human beings, then natural immunity may not develop 'slowly'. Instead, immunity may develop after relatively few infections to a level determined by intrinsic immune factors that change with age. This is the hypothesis of age-dependent immunity to $P$. falciparum.

\section{Early Observations}

In 1919 Schüffner published the results of an investigation of epidemic malaria at Sundatar, Sumatra (Schüffner, 1919). He found that the prevalence of parasitaemia was lower among adults than children. Schüffner understood Koch's hypothesis of acquired immunity and its requirement for lifelong uninterrupted exposure. The lack of that degree of exposure at Sundatar and the age-dependent protection from parasitaemia puzzled Schüffner. He wondered, 'Why do these persons [adults] behave differently from the others? Are they more resistant simply because of age ... ?' A few years later, Christophers (1924) found that older newcomers to a mining camp in a hyperendemic area of India showed 'inexplicable' resistance to infection compared with the young. However, Schüffner and Christophers both suspected prior exposure in the presumably non-immune subjects, and neither addressed the issue.

Among the many cross-sectional studies of malaria in endemic areas in this century, there appear to be no others in which adequate numbers of subjects of all ages who were being suddenly exposed to hyper- or holoendemic malaria were investigated. Such a study would be key because separate analyses of the effects of age $v$. cumulative exposure are not possible when the subjects have lived their entire lives in endemic regions. The circumstances leading non-immune adults and children to take up residence in a heavily malarious area are apparently rare, and reportable clinical evaluation and surveillance of them rarer still.

Transmigration and Malaria on Java The Indonesian government conducts a programme to encourage migration from the heavily populated islands of Java and Bali to the sparsely populated, major, outer islands of Sumatra, Kalimantan (Indonesian Borneo), Sulawesi (Celebes) and Irian Jaya (Indonesian New Guinea). From the perspective of sorting the effects of age and cumulative exposure to malaria, transmigration offers the opportunity for key analytical insights. The island targets of transmigration are heavily malarious, whereas little malaria transmission has occurred on Java or Bali since before 1960. [The incidence of malaria on Java has remained at approximately 0.15 cases $/ 1000$ person-years since 1960 (Atmosoedjono, 1990).] Malaria transmission has been restricted to a few distinct foci of hypo-endemic malaria in Central Java (Baird et al., 1996). If the cases and populations of these endemic foci are removed from the estimation, the incidence of malaria for over $99 \%$ of the 113 million people on Java falls to approximately 0.02 cases $/ 1000$ person-years. Thus, 1000 transmigrants from Java with a mean age of 25 years (a typical village, representing 25000 person-years of risk on Java) should have experienced, on average, less than a single case of malaria.

Malaria in Javanese Transmigrants in Irian Jaya

During 1987 and 1988 a longitudinal study of malaria among Javanese transmigrants living in Irian Jaya produced data pointing to the rapid acquisition of natural immunity by the adults but not by the children (Baird et al., 1991). The transmigrants investigated had been living in a village for 19 months when the study commenced. Their neighbours in the village were lifelong residents of Irian Jaya. Accepting the premise that naturally acquired immunity was the cumulative product of many years of uninterrupted exposure, the susceptibility of the transmigrants was studied relative to that of the Irianese natives. 


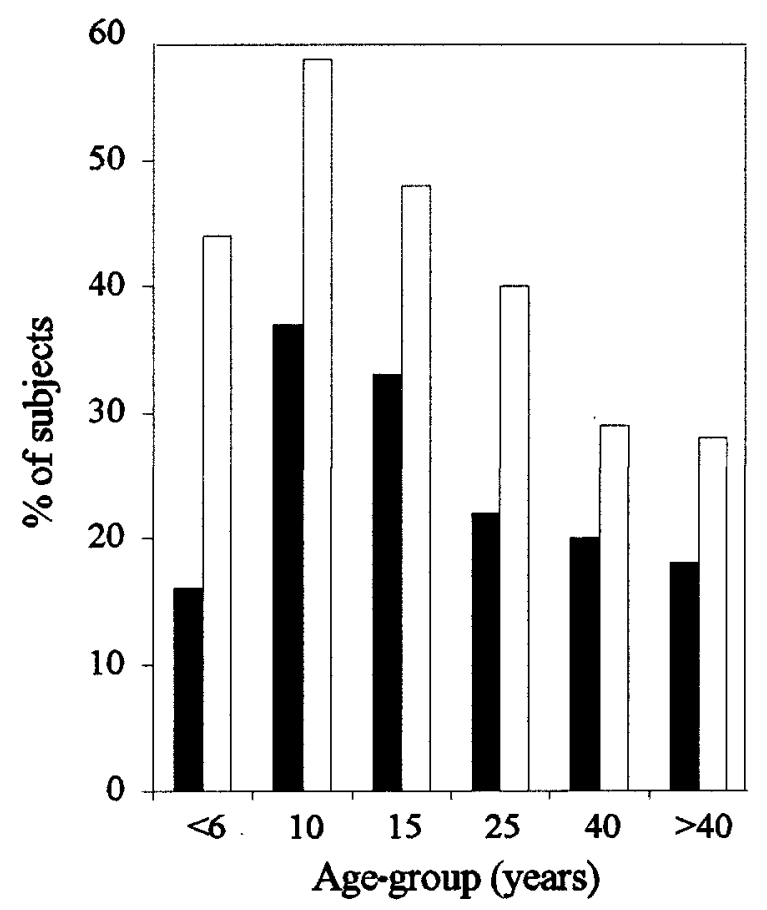

Fig. 3. Age-specific prevalences of $P$. falciparum parasitaemia $(\square)$ and spleen 'rates' $(\square)$ among 701 Javanese transmigrants after 5 years' residence in Irian Jaya (Baird et al., 1993).

The anticipated pattern did not emerge; whereas the Javanese had slightly higher agespecific prevalences of $P$. falciparum, the distribution of prevalence among the age-groups of Javanese was parallel to that among the natives of Irian Jaya (Figs 3 and 4). This pattern was also true for the median time to first parasitaemia, density of parasitaemia, spleen 'rate', and symptoms of malaria. Although the transmigrants had $<2$ years' exposure, their age-specific susceptibility to falciparum malaria was parallel to that in the lifelong residents (Baird et al., 1991). Cumulative exposure did not therefore govern efficacy of naturally acquired immunity to $P$. falciparum in this study population.

Subsequent, cross-sectional studies of falciparum malaria in six other transmigration villages in the same region again showed age-dependent prevalence after 1-2 years' exposure. Prevalence in these villages was closely linked to spleen 'rates', indicating that the pattern observed was unrelated to sampling bias (Fig. 3; Baird et al., 1993). Plots of age-specific parasitological estimates of protective immunity (i.e. the density and frequency of parasitaemia) among Javanese transmigrants (Baird, 1995) run parallel to plots of the same estimates in lifelong residents of holo-endemic Africa (McGregor and Smith, 1952). Data from six transmigration villages sampled on 15 occasions (with a mean sample of 304 subjects/village on each occasion; range $=91-701$ subjects/village) show that onset of natural immunity in Javanese transmigrants was dependent on age rather than lifelong exposure (Baird et al., 1993). Recent hyperendemic exposure established a protective immunity that was more effective in adults than in children.

Another study of transmigrants in Irian Jaya (Andersen et al.,1997) confirmed the agedependent pattern in parasite densities but 
(a)

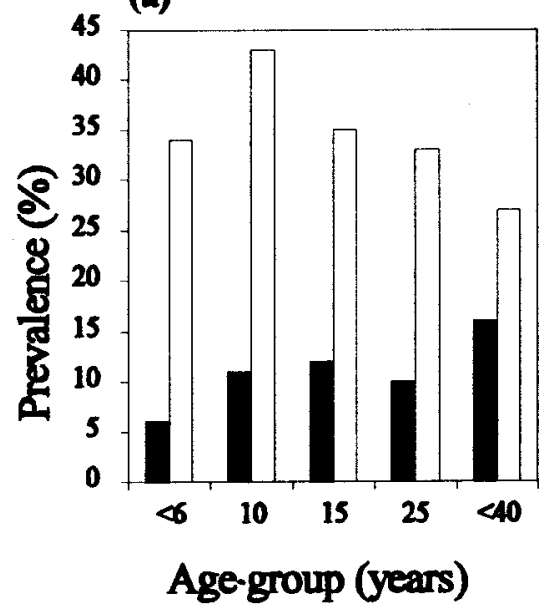

(b)

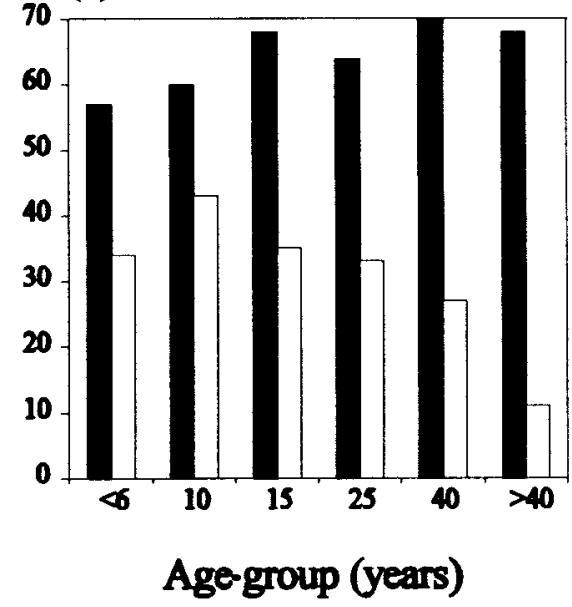

Fig. 4. Prevalence of parasitaemia is largely uniform among groups during early exposure, and only later establishes an age-dependent pattern. (a) Prevalence of $P$. falciparum in Javanese transmigrants after they had lived in Arso PIR IV, Irian Jaya, for 1 month $(\square ; N=108)$ and after they had lived in the same village for 15 months $(\square ; N=223)$. (b) Prevalence of $P$. falciparum in Javanese transmigrants after they had lived in Arso, Irian Jaya, for 8 months $(\square ; N=689)$ and after they had lived in the same village for 20 months $(\square ; N=553)$.

failed to do so with age-specific parasite frequencies. However, only 66 subjects from two villages with a total population of $>2000$ people were investigated. The sample size, in view of the reported insignificant differences in parasite frequencies among groups, may have been inadequate to draw meaningful statistical inference.

Confounding of the age-related pattern of parasitaemia by drug use or vector feeding behaviour was considered as an explanation for the age-dependent prevalence of parasitaemia. A survey of antimalarial consumption among the Javanese transmigrants revealed that the children were more likely to have recently consumed an antimalarial drug (chloroquine or Fansidar) than the adults (Baird et al., 1991). Drug usage in children was an unlikely explanation for the low levels of parasitaemia among the adults. Differential exposure to biting mosquitoes was also an unlikely explanation. The anopheline vectors fed in the village from dusk to dawn, and outdoors as frequently as indoors-there was relatively uniform exposure to biting mosquitoes among age-groups. Independent studies have shown that anopheline mosquitoes show no preference for children over adults (Bryan and Smalley, 1978; Port et al., 1980; Burkot et al., 1988).

Perhaps the best evidence that the agerelated pattern of prevalence was not solely the product of confounding or bias was the absence of an age-related pattern during early exposure to infection. If sampling bias, prior exposure to infection, drug consumption, or mosquito feeding patterns explained the agerelated distribution of prevalence, then the pattern should have been evident soon after exposure commenced. It was not. The prevalence of parasitaemia soon after onset of exposure was either relatively uniform among age-groups or slightly higher among adults [Fig. 4(a) and (b)]. Establishment of the agedependent pattern of prevalence of parasitaemia required 1-2 years of exposure to infection.

An incidence of three $P$. falciparum infec- 


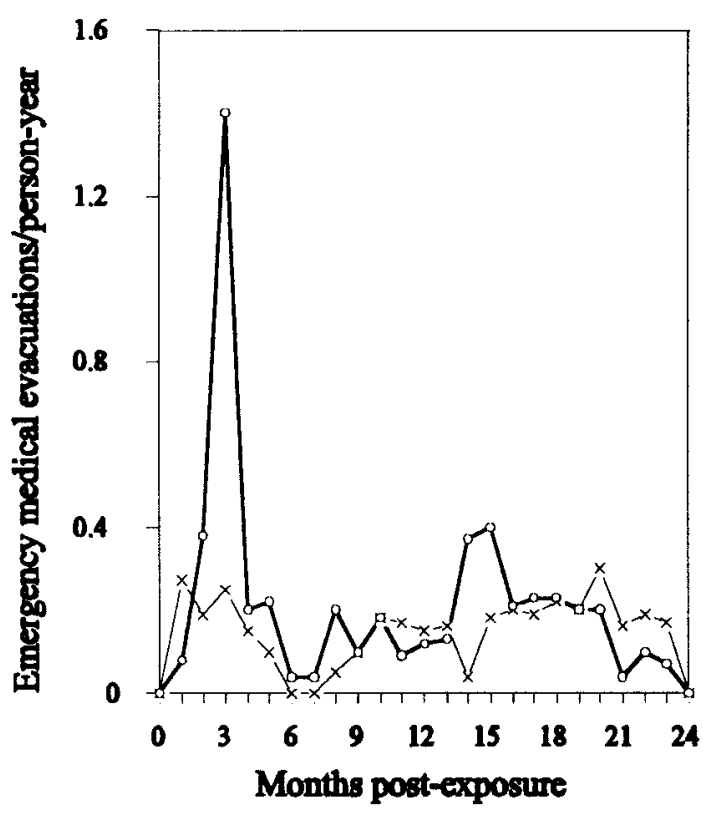

Fig. 5. Incidence of emergency medical evacuation to hospital with a diagnosis of malaria among children $(\times)$ and adults $(\bigcirc)$ from Arso PIR IV in Irian Jaya (Baird et al., 1998).

tions/person-year was measured in transmigration areas in north-eastern Irian Jaya (Jones et al., 1994). Over the course of 1-2 years, therefore, an estimated total of three to six infections would have occurred in each person. This exposure was apparently sufficient to induce a pattern of age-dependent protection against frequent and high-density parasitaemia in adults. The exposure requirement for onset of heterologous immunity in the Javanese transmigrants approximated that for onset of presumably homologous immunity among neurosyphilis patients (Fig. 2). Conversely, the relative susceptibility of Javanese children to parasitaemia after the same degree of exposure may be attributed to intrinsic differences in immune function related to the normal development and ageing of the human host.

Adult Susceptibility to Acute Exposure to $P$. falciparum

The susceptibility of children to chronic exposure to $P$. falciparum has dominated studies of natural immunity. What happens with acute exposure to infection? Are children and adults equally susceptible, or do intrinsic, agerelated differences in immune function create important differences? The available data point to a surprising conclusion: adults appear to be more susceptible than children to severe morbidity and mortality after acute exposure to $P$. falciparum.

Three months after transmigrants from Java arrived in hyperendemic Irian Jaya, adults had a 7-fold higher incidence of emergency medical evacuation with a provisional diagnosis of malaria than their children (Baird et al., 1998; Fig. 5). After 6 months in Irian Jaya, 148 of 639 adults (aged $>15$ years) had been evacuated to hospital with life-threatening malaria, compared with 36 of 420 children $(P<0.00001 ; \quad$ relative risk $=2.7 ; \quad 95 \%$ confidence interval $=1.8-4.2)$. Similar observations have come from a variety of sources. Greenberg and Lobel (1990) reported age- 
(a)

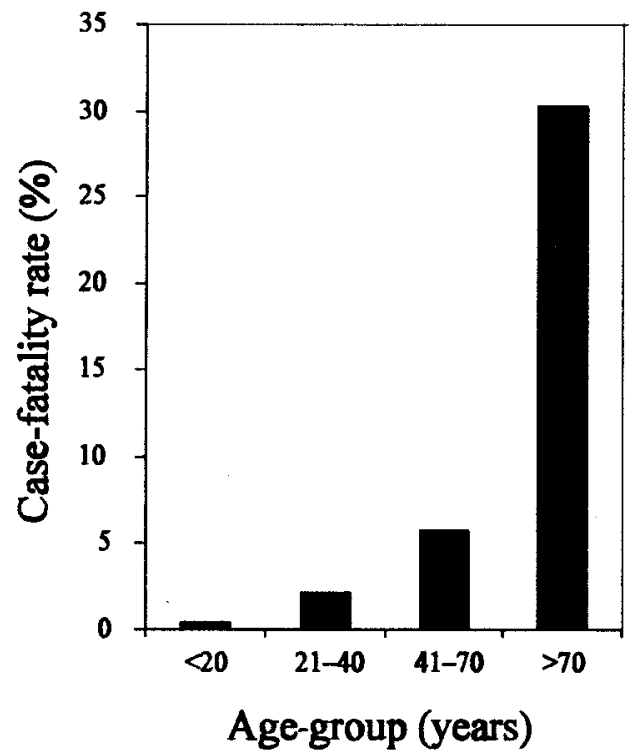

(b)

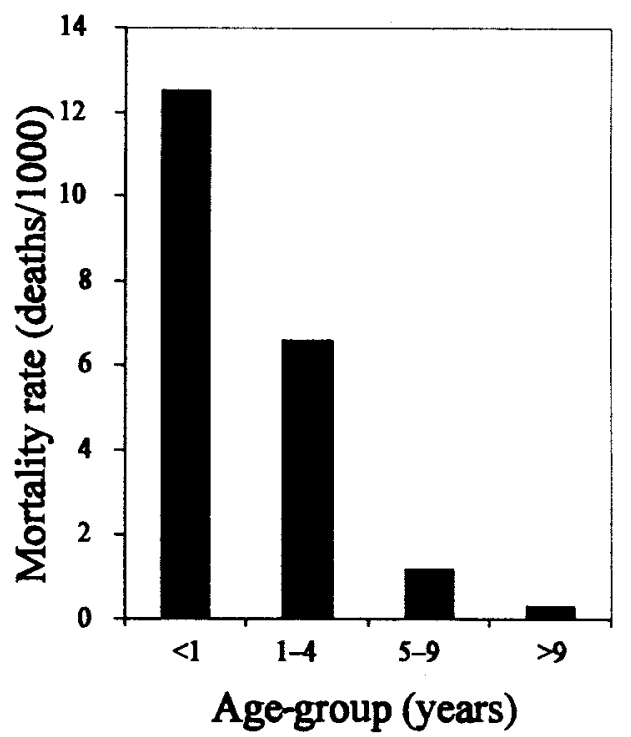

Fig. 6. Age-related susceptibility to death in populations having acute or chronic exposure to infection. (a) The case-fatality rate for the 1111 American civilians (68 deaths) who acquired malaria while travelling abroad between 1959 and 1987 and were treated in hospitals in the U.S.A. (Greenberg and Lobel, 1990). (b) The mortality rate for children and adults (adults included in group reported as $>9$ years old) residing in holo-endemic West Africa (Bruce-Chwatt, 1952).

specific, case-fatality rates for 1111 Americans acquiring malaria abroad and obtaining treatment in hospitals in the U.S.A. between 1959 and 1987 [Fig. 6(a)]. A gradual increase in susceptibility to fatal malaria occurred with increasing age. The greatly increased rate of death by malaria among patients $>70$ years of age was undoubtedly enhanced by underlying risk of death to the typical diseases of the elderly. Nonetheless, subjects of middle age had 5-fold to 15-fold higher risk of death than patients $<20$ years of age. Among patients hospitalized with severe malaria in KwaZulu/ Natal, 15 of the 111 aged $>12$ years died whereas no deaths occurred among the 32 younger subjects (odds ratio $>4.8 ; P<0.01$; Soni and Gouws, 1996). Other studies from Germany (Buck and Eichenlaub, 1994), Vanuatu (Bastien, 1987), Kenya (Some, 1994) and Senegal (Sarthou et al., 1997) also show an exaggerated susceptibility in adults relative to that in children. In an epidemic of malaria that killed over 100000 people in Ceylon (Sri Lanka) in 1932, Gill (1936) reported data showing higher case-fatality rates in adults than in the children $(P<0.0001$; relative risk $=2.1 ; 95 \%$ confidence interval $=1.9-2.3$ ).

What could account for these marked differences in susceptibility between children and adults following acute exposure to $P$. falciparum? Clarke (1983) reported that adult rats (each weighing about $185 \mathrm{~g}$ ) were twice as sensitive to the harmful effects of endotoxin as younger (65-g) rats. This pattern correlated with the age-related innate susceptibility to death following infection with $P$. berghei. The relevance of these findings in a murine system remains to be established, but the possibility of a parallel mechanism in humans exposed to $P$. falciparum merits clinical investigation. 
The observed effect of host age on the probability of severe disease following initial exposure to $P$. falciparum demonstrates that age-dependent changes in the immune system modulate the course of infection. Apart from the obvious clinical importance, this finding indicates that the age-related immunity seen with chronic exposure may also be mediated by intrinsic age-dependent changes in immune function rather than by the cumulative effect of many years of heavy exposure. The striking inversion of age-related patterns of susceptibility between acute [Fig. 6(a)] and chronic [Fig. 6(b)] exposure to malaria cannot yet be explained. Nonetheless, an examination of age-related changes in immune function may provide clues to guide investigation in this area.

\section{Developmental Changes in Immune Function \\ The hypothesis of age-dependent immunity to $P$. falciparum attributes the essential differ- ences in the susceptibility or resistance to infection between adults and children to as yet unidentified changes in the immune system that occur during normal ageing. What could these changes be, and what impact could they have on the course of malaria? Some possibil- ities are considered below.}

$\mathrm{CD}^{+}$T-CELl SUbPOPUlations: NAIVE AND MEMORY VERSUS Th1 AND Th2

Studies in mice have established the existence of functionally distinct Th1 and Th2 subpopulations of $\mathrm{CD}^{+} \mathrm{T}$ cells. This distinction is less clear in human $\mathrm{CD}^{+}$cells but generally acknowledged. A Th1-type response may be characterized by the production of interferon$\gamma$ (IFN- $\gamma$ ) but not interleukin-4 (IL-4). Conversely, Th2-type responses are marked by the production of IL-4 but not IFN- $\gamma$ (Romagnani, 1996). Other cytokines also mark Th1or Th2-type responses. For example, tumour necrosis factor (TNF) and IL-2 typically mark the Th1-type, whereas IL-5, IL-6, IL-10, and IL-13 indicate a Th2-type response (Lucey et al., 1996). There are also a minority of CD $4^{+}$T-cell clones that seem ambiguous with respect to cytokine-profile phenotypes and have been deemed Th0-type cells.

A variety of markers distinguishes naive and memory subpopulations of CD4 ${ }^{+} \mathrm{T}$ cells, but none reliably distinguishes $\mathrm{Th} 1$ from $\mathrm{Th} 2$ as defined by the cytokine-production repertoires already mentioned. The phenotype CD4 CD $45 \mathrm{R}^{\text {hi }}$ has been linked to Th1-type-dominated responsiveness, whereas populations of CD4 CD45 $\mathrm{R}^{10}$ cells show responsiveness of the Th2-type (Bottomly, 1988; Lee et al., 1990). However, expression of CD4 CD45R in cell populations seems better correlated with naive- $v$. memory-dominated, T-cell populations (Mosmann and Sad, 1996). CD $44^{\text {lo }}$ and CD44 $4^{\text {hi }}(\mathrm{Pgp}-1)$ on $\mathrm{CD}^{+}$cells mark the transition from naive to memory, and in the mouse model correlate with the CD45R ${ }^{\text {lo }}$ phenotype (Budd et al., 1987; Ernst et al., 1990).

Activated, naive $\mathrm{T}$ cells typically generate a Th1-like repertoire of cytokines, whereas memory $\mathrm{T}$ cells respond with predominantly Th2-like cytokines (Budd et al. 1987; Ernst et al., 1990, 1993a, b, Ehlers and Smith, 1991; Lee and Vitetta, 1991; Bining and Miller, 1997). Some immunologists have considered the functional $\mathrm{Th} 1$ designation as synonymous with naive $\mathrm{T}$ cells, and $\mathrm{Th} 2$ as synonymous with memory $\mathrm{T}$ cells (Hirokawa et al., 1994). However, memory $\mathrm{T}$ cells may produce IFN$\gamma$ (Hobbs et al., 1993; Ernst et al., 1993a), and naive $\mathrm{T}$ cells may differentiate to cell populations having either Th1- or Th2-like functional attributes. Thus, the Th1 and Th2 distinction cannot be extrapolated to the distinctions in naive $v$. memory $\mathrm{T}$-cell markers. Differentiation of naive $\mathrm{T}$ cells to the Th1like phenotype is driven by cytokines such as IL-12, and differentiation to Th2-like $\mathrm{T}$ cells is driven by IL-4 (Swain et al., 1990; Seder et al., 1993). Whereas the age-related changes in naive $v$. memory $T$ cells are well established in mice and humans, whether these changes correspond to a similar shift between Th1-like and Th2-like responsiveness remains uncertain.

AgE-RELATED CHANGeS IN T-CELl POPUlaTIONS

Profound changes in immune constitution and 


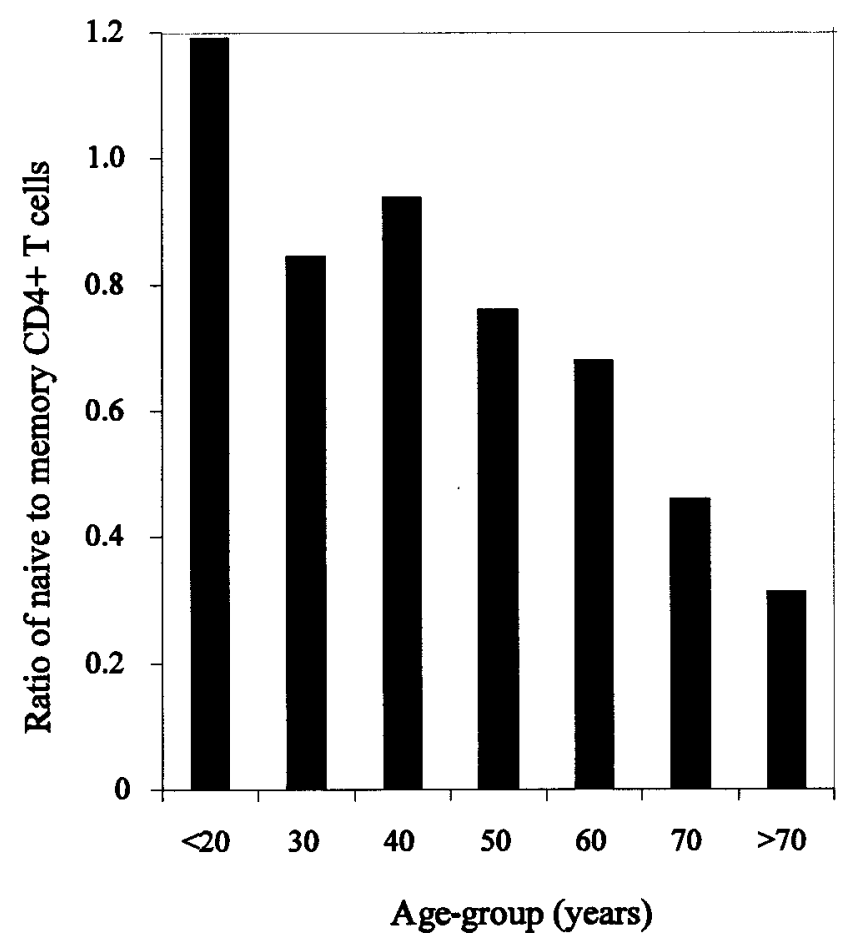

Fig. 7. The falling ratio of naive to memory $\mathrm{CD}^{+} \mathrm{T}$ cells in humans of increasing age, as reported by Hirokawa (1994).

function occur throughout life. The most prominent occurs in the structure and function of the thymus and the capacity to induce intrathymic growth and differentiation of $\mathrm{T}$ cells. The thymus reaches peak activity at puberty and thereafter slowly atrophies (Boyd, 1932). An older thymus contains mostly macrophages and relatively few lymphocytes (Hirokawa, 1977). Older rodents and humans generate diminished lymphoproliferative responses to mitogens and antigens compared with their young, induction of $\mathrm{T}$-cell differentiation wanes with age, and the proportion of functionally impaired CD $4^{+} \mathrm{T}$ cells increases with age (Lewis et al., 1978; Kishimoto et al., 1978; Makinodan and Kay, 1980; Nagel et al., 1981; Vie and Miller, 1986; Iwashima et al., 1987; Makinodan et al., 1987; Murasko et al., 1987; Thoman and Weigle, 1989; Utsuyama et al., 1991; El Demellawy and El
Ridi, 1992; Kariv et al., 1992; Doria and Frasca, 1994; Weksler, 1994; Pahlavani and Richardson, 1996). Evidence in mice and humans points to impaired activity of $\mathrm{CD} 4^{+} \mathrm{T}$ cells with increasing age, especially when measured by functional impairment of IL-2 (Pahlavani and Richards, 1996).

Another important age-related change in CD4 ${ }^{+} \mathrm{T}$-cell function is the gradual decrease in the ratio of naive to memory $\mathrm{T}$-cell subpopulations among $\mathrm{CD}^{+}{ }^{+} \mathrm{T}$ cells (Table 1$)$. The data reported by Hirokawa et al. (1994), who distinguished human cells according to $\mathrm{CD}^{+}{ }^{+} \mathrm{CD} 45 \mathrm{RA}^{+}$(naive) and $\mathrm{CD} 4{ }^{+} \mathrm{CD} 29^{+}$ (memory) markers, show this clearly (Fig. 7). Similar changes have been documented in other humans (Utsuyama et al., 1992) and in mice (Ernst et al., 1990; Hirokawa et al., 1992), using these and other markers (CD44 or 3G11). Studies of splenic $\mathrm{CD}^{+} \mathrm{T}$ cells 
TABLE 1

Age-rela ted changes in the surface markers of $\mathrm{CD}^{+} \mathrm{T}$ cells in mice and humans

\begin{tabular}{|c|c|c|c|c|c|}
\hline \multirow[b]{2}{*}{ Marker } & \multirow[b]{2}{*}{$T$-cell subclass } & \multirow[b]{2}{*}{ Animal } & \multicolumn{2}{|c|}{ Frequency of marker in: } & \multirow[b]{2}{*}{ Reference } \\
\hline & & & Young a nimals & Old a nimals & \\
\hline $3 \mathrm{G} 11$ & Naive & Mouse & High & Low & Hayakawa and Hardy (1989) \\
\hline Pgp-1/CD44 & Memory & Mouse & Low & High & Budd et al. (1987) \\
\hline CD45RB & Naive & Mouse & High & Low & Bottomly (1988) \\
\hline CD45RA & Naive & Human & High & Low & Utsuyama et al. (1992) \\
\hline CD29 & Memory & Human & Low & High & Utsuyama et al. (1992) \\
\hline CD45RO & Memory & Human & Low & High & Sanders et al. (1988) \\
\hline
\end{tabular}

from young and aged mice showed relatively high levels of CD44 and low levels of CD45RB in the older mice (Ernst et al., 1990). Naive and memory $\mathrm{T}$ cells have distinct lymphokine-production repertoires (Ernst et al., 1993b). The ratio of naive to memory $T$ cells may influence the course of malaria, especially if cross-reactive antigens play a role in the immune response to infection (see below).

Distinctions in $\operatorname{IgG}$ subclasses may be important to understanding protection against $P$. falciparum. Changes in subclass expression have been linked to age-dependent cytokine balances that effect Ig-class and -subclass expression (Hara et al., 1987; Antonaci et al., 1992). The proportion of IgG antibodies of the cytophilic subclasses $\left(\operatorname{IgG}_{1}\right.$ and $\left.\operatorname{IgG}_{3}\right)$ increases with age among children (Gregorek et al., 1994) and adults (Powers, 1994; Yachie et al., 1995). IgG-subclass ratios are apparently regulated by cytokines; IL-2 and IL-12 induce $\mathrm{IgG}_{2}$ whereas IL-6 and IL-10 (Th2type cytokines) induce $\mathrm{IgG}_{1}, \mathrm{IgG}_{3}$ and $\mathrm{IgG}_{4}$ (Briere et al., 1994; Kawano et al., 1994, 1995; Buchanan et al., 1995; Lorenz et al., 1995; Van Cleave et al., 1995; Kawano and Noma, 1996). Mice challenged with $P$. chabaudi chabaudi produced $\mathrm{IgG}_{2}$ when the immune response was dominated by Th1 cytokines, and later switched to Th2 cytokines and predominance of $\operatorname{IgG}_{1}$ (D'Imperio et al., 1996).

\section{CROSS-REACTIVE ANTIGENS}

It may be difficult to separate the effects of developmental changes from those of exposure to ubiquitous antigens. People lacking exposure to malaria may recognize malaria antigens, perhaps because of antigenic crossreactivity between epitopes in malarial parasites and other microorganisms (Good et al., 1987; Jones et al., 1990; Good, 1991, 1995; Beverly, 1994). Exposure to myriad immunogenic microorganisms throughout life is unavoidable. The accumulation of memory to these antigens and the likelihood of incidental cross-reactivity with antigens from malarial parasites probably increases with age. In the context of this review, the accumulation of a repertoire of potentially cross-reactive memory is considered essentially developmental (i.e. inevitable and fairly uniform in the population as a whole). Indeed, continuous exposure to a broad variety of antigens per se could be an essential aspect of immunological maturation. Nonetheless, Ortega-Mora and Wright (1994) addressed this issue with the age-related immunity to Cryptosporidium parvum in lambs reared in 'disease-free' environments; age-dependent immunity directed against the parasite persisted despite protection from other sources of antigenic stimulation.

No attempt has been made in this review to separate purely developmental, immunological changes from those induced by exposure to other antigens, some of which may cross-react with malarial antigens. Nonetheless, the potentially important role for such crossreactivity in an age-dependent immune process should be recognized. For example, if 
(a)

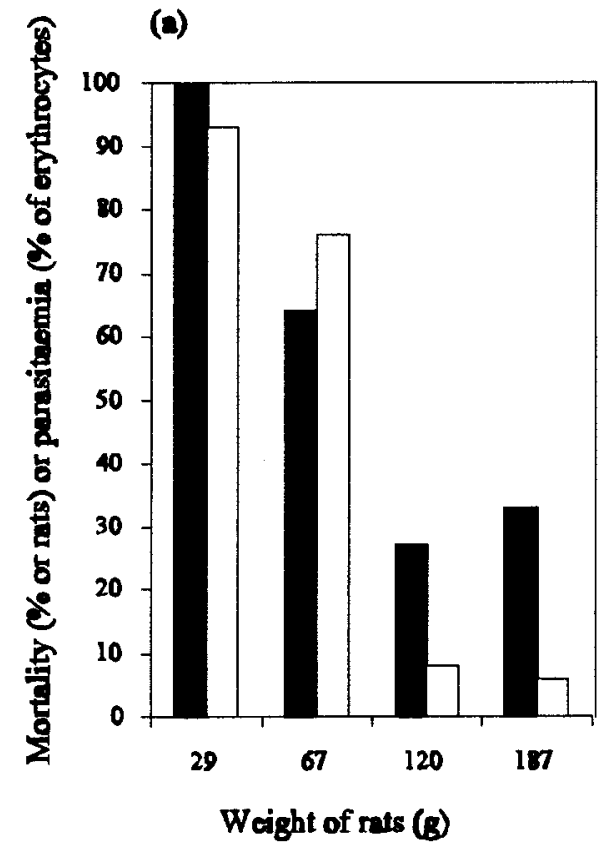

(b)

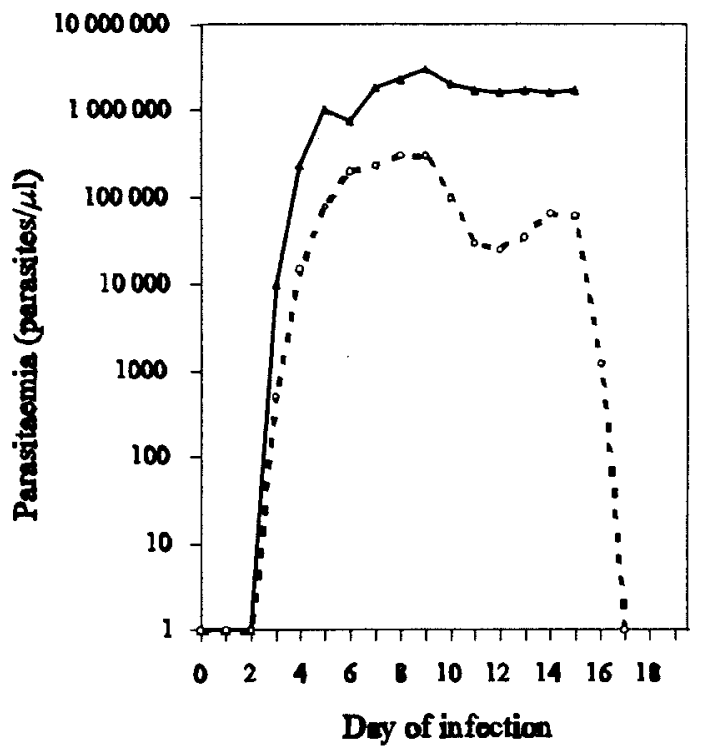

Fig. 8. (a) Mortality $(\square)$ and peak parasitaemia $(\square)$ following challenge of 107 naive albino rats of varying age (as reflected by weight) with the blood-stages of $P$. berghei (Zuckerman and Yoeli, 1953). (b) Course of parasitaemia in Sprague-Dawley rats aged 30 days $(\boldsymbol{\Delta} ; N=10)$ or 81 days $(O ; N=10)$ when challenged with $P$. berghei-infected red blood cells. Nine of the 10 young rats died but all the older rats survived (Singer et al., 1955).

cross-reactive antigens selectively stimulate memory $\mathrm{T}$ cells and spur a Th2-like response, this may have important age-related consequences upon the course of infection by Plasmodium spp. Given the data shown in Fig. 7, the probability of such cross-reactivity would seem to increase as a function of age. Agespecific patterns of cytokine production by non-imm une $\mathrm{T}$-cell populations stimulated by malarial antigens have not been reported.

Age-dependent Immune Function in Murine Malaria Models

$\mathrm{T}$-cells are critical mediators of protection against murine and human malarias (TroyeBlomberg et al., 1994; Taylor-Robinson, 1995). This is especially true of the $\mathrm{CD}^{+}{ }^{+} \mathrm{T}$ cells against blood-stage infection. Changes occurring in $\mathrm{T}$-cell populations through normal development may affect the efficacy of both humoral and cell-mediated protection. There are data demonstrating that changes related to age per se profoundly influence the course of malaria in animal models.

The first study addressing susceptibility to malaria in experimental animals as a function of age was by Coggeshall (1938). Coggeshall isolated $P$. lophurae from a Borneo pheasant and adapted it to ducks, where he showed that susceptibility decreased markedly with age. The same 'age resistance' was later reported for $P$. lophurae in chickens (Trager and McGhee, 1950). The susceptibility of rodents to challenge with $P$. berghei blood-stages also decreased with age (Raffale and Baldi, 1950). Zuckerman and Yoeli (1953) infected outbred, albino rats with $P$. berghei and found that age 
profoundly influenced mortality and peak parasitaemia [Fig. 8(a)]. Virtually all the rats which were aged 14-30 days when infected died, whereas fewer than one in three of the 114-day-old rats died. Singer et al. (1955) reported similar observations; nine of 10, 30day-old, Sprague-Dawley rats died following $P$. berghei challenge whereas all 10, 81-day-old rats eliminated their infections [Fig. 8(b)]. Innate immune factors (e.g. reticulocyte availability) contributed to the differences between young and old rats but age-dependent immunity appeared largely acquired. Singer et al. (1955) concluded, ' ... reticulocyte availability limited intensity of infection only until such a time as the host was able to produce an (acquired) immune response sufficient to control parasitemia. The ability to produce such a response appeared to vary directly with the age of the rat.' The prolonged plateau of peak parasitaemia in this model may be analogous to the chronic exposure of humans.

The ability of Spira et al. (1970) to abolish age-dependent immunity against $P$. berghei in Lewis rats by treating the rodents with rabbit anti-rat-thymocyte sera indicated a T-cellmediated basis for such immunity. Alger et al. (1972) demonstrated age-dependent protective immunity against $P$. berghei in inbred A/J mice, and Kasper and Alger (1973) adoptively transferred this immunity from old to young mice using splenic $\mathrm{T}$ cells. Like untreated controls, naive, 4-week-old mice receiving cells from naive, 6-8-month-old retired breeders died within 30 days of challenge, each with a fulminant parasitaemia. In contrast, when spleen cells from an exposed retired breeder were transferred to 4-week-old mice, parasitaemias cleared spontaneously within 15 days. Transfer of spleen cells from exposed, 6-week-old mice failed to clear parasitaemia after 34 days. Age-dependent immunity in these experiments was acquired and linked to T-cell-mediated immune function. The agerelated protection against malaria in rodents was mediated by exposure, age at first exposure, and splenic T cells.

The resistance to $P$. berghei in adult rodents and susceptibility in juvenile rodents observed in these early experiments accords with the hypothesis of age-related immunity against chronic exposure to $P$. falciparum. Those observations in rats seem discordant with adult susceptibility to acute exposure. However, by some measures the older rats were more susceptible than the younger: crisis occurred sooner and with parasitaemias of lower density (Zuckerman and Yoeli, 1953). Although fewer older rats died, the deaths that did occur in the older animals occurred sooner than in the younger rats. The establishment of chronic infection protected older better than younger rats, whereas older rats were initially more susceptible to infection. Whether infection is acute or chronic may profoundly influence the age-related immunity against malarial parasites in rodents. Direct experimental evidence of this is needed (e.g. from studies of Th1 v. Th2 immune responses in young and old mice exposed to acute and chronic infection).

Age-dependent Immunity in Acute v. Chronic Exposure

Why are human adults more susceptible than children to severe morbidity and mortality at first infection? Why is the onset of acquired protective immunity against chronic exposure more rapid in adults than juveniles? Normal developmental changes in human $\mathrm{T}$-cell function may help explain these questions. Compared with their young, older humans and other animals have $\mathrm{T}$-cell populations with diminished lymphoproliferative responses to mitogens and antigens, are unable to induce $\mathrm{T}$-cell differentiation as well, and have relatively high proportions of functionally impaired T cells (Hirokawa et al., 1994). An extensive body of literature, reviewed by Pahlavani and Richardson (1996), documents markedly diminished expression of IL-2 during the process of ageing. The susceptibility of adult humans to natural infection with $P$. falciparum may be related to these normal consequences of ageing.

\section{CHRONIC EXPOSURE}

Studies of humans under chronic exposure to malaria show a consistent age-related pattern of Th1- $v$. Th2-like responsiveness. It should 
be noted that factors beyond the control of investigators often confound studies of cellular immunity in endemic populations. For example, activated lymphocytes may migrate out of the peripheral circulation. Acute infection may cause a general suppression of lymphoproliferative responses, and selfadministered therapeutic agents may have an impact on the cell-mediated immune response. Moreover, separation of study subjects into 'protected' and 'unprotected' groups usually involves a separation on the basis of age (i.e. adults and children, respectively). When cell-mediated immune activity in adults and children is compared in this setting, children usually show results consistent with a Th1-like response. Conversely, adults often show results consistent with dominance of the immune response by Th2like cytokines.

Elevation of IL-4 with suppression of IFN- $\gamma$ is the hallmark of a Th2-like immune response, along with elevated levels of $\mathrm{IgG}_{1}$ relative to $\operatorname{IgG}_{2 \mathrm{a}}$. This profile characterises the immune responses to malarial antigens that have been observed in aparasitaemic or asymptomatic adults living in hyper- to holoendemic areas. In Burkina Faso, T-cells from parasitaemic children produced higher levels of IFN- $\gamma$ than $\mathrm{T}$ cells from aparasitaemic adults, in response to in-vitro stimulation with Pf155/RESA antigens (Elghazali et al., 1995). Similar peptides induced IL-4 transcription and expression in $\mathrm{T}$ cells from adult donors who had elevated levels of antibodies to the same peptide used for the in-vitro stimulation (Troye-Blomberg et al., 1990). Boudin et al. (1994) reported that, in a matrix of immunological parameters of responsiveness to an array of parasite antigens among children and adults living in holo-endemic Burkina Faso, adults tended to have higher humoral and lower cellular immunity than children. Lymphocytes from parasitaemic children in an endemic area produced IFN- $\gamma$ when stimulated with antigens from $P$. falciparum, indicating a predominantly Th1-like response to infection (Riley et al., 1991). Riley et al. (1992) measured humoral and lymphoproliferative responses to discreet peptides of merozoite-surface-protein-1 (MSP-1) of $P$. falciparum, as well as those to the whole protein, among Gambian children and adults. Lymphoproliferative responses against each of the peptides tested peaked in childhood and then either remained at a high level of stimulation or diminished with age. Conversely, the children consistently had lower levels of antibodies to these proteins than the adults. Mshana et al. (1991) measured plasma concentrations of IFN- $\gamma$, TNF- $\alpha$, IL- 4 and IL- 6 among residents of holo-endemic Gabon. Whereas IFN- $\gamma$ and TNF- $\alpha$ diminished with increasing age, IL-4 and IL-6 increased. This is consistent with a Th1- to Th2-like shift in immune responsiveness to chronic exposure to infection. Finally, naive $\alpha \beta \mathrm{T}$ cells from non-immune humans (the cells which would predominate in younger persons; see above) produced IFN- $\gamma$ but not IL-4 in response to membrane components of red blood cells infected with $P$. falciparum (Dick et al., 1996).

Analysis of the available data on IgG subclasses also hints to a predominance of the Th1-like response to chronic exposure during childhood giving way to a Th2-like response in adulthood. The passive transfer of protective immunity in the $\operatorname{IgG}$ of adult West Africans to acutely ill Thai patients (Sabcharoen et al., 1991) has been attributed to the predominance of $\operatorname{IgG}_{1}$ and $\operatorname{IgG}_{3}$ (Bouharoun-Tayoun and Druilhe, 1992) in immune sera. Adult subjects from the Solomon Islands had predominantly $\operatorname{IgG}_{1}$ and $\mathrm{IgG}_{3}$ against crude, schizont antigen (Rzepczyk et al., 1997). Among Gambians, Egan et al. (1995) found age-related increases in antibodies against the $19-\mathrm{kD}$ a fragment of $P$. falciparum MSP-1 and that the antibodies were predominantly of the $\mathrm{IgG}_{1}$ subclass. Shi et al. (1996) found that $\operatorname{IgG}_{1}$ and $\operatorname{IgG}_{3}$ against natural variants of the $19-\mathrm{kDa}$ domain of MSP-1 increased with age and that the titres of $\mathrm{IgG}_{1}$ within age-groups correlated with relative protection. Taylor et al. (1995) found that the predominant subclasses of $I g G$ to a panel of recombinant MSP-2 antigens among Gambian adults were $\operatorname{IgG}_{1}$ and $\operatorname{IgG}_{3}$. 
Although $\operatorname{IgG}_{3}$ has been found to be elevated under Th1-like stimulation (Kawano and Noma, 1996), other studies have shown that relative levels of $\mathrm{IgG}_{3}$ increase with age and that this subclass can be stimulated by IL-6 and IL-10, Th2-like cytokines (Briere et al., 1994; Kawano et al., 1995). Predominance of $\mathrm{IgG}_{2}$ has been reported from the serum of children living in endemic areas (Bouharoun-Tayoun and Druilhe, 1992). Finally, $\operatorname{IgE}$ is also a Th2 immunoglobulin and malaria-specific IgE occurs in adults living in endemic areas (Desowitz, 1989; Desowitz et al., 1993; Perlmann et al., 1994).

Taken together, these observations from people living under chronic exposure to malaria suggest a shift from a Th1-like immune response in children to a Th2-like response in adults. In view of the data illustrated in Fig. 1, it seems likely that protection against chronic exposure to falciparum malaria may correlate with a tendency toward Th2-like activity against the parasite. Conversely, childhood susceptibility to the frequent and high-grade parasitaemias of chronic exposure may be related to an inclination toward the Th1-like pole of activity.

\section{ACUTE EXPOSURE}

The cytokine-production repertoires among populations suddenly exposed to falciparum malaria may not be characterised with the scarcely available data. If adults tended toward a Th2-like response to acute infection, and children Th1-like, then the relative susceptibility of adults would accord with that in the mouse models (i.e. susceptibility linked to a primary response to infection, dominated by a Th2-like cytokine-production response; Table 2). Likewise, the relative resistance of children to severe disease may accord with dominance of a Th1-like response to primary infection, as in mouse models. Figure 9 illustrates the hypothetical relationships between the age-related immune response and resistance or susceptibility to acute or chronic exposure to infection. The data needed to test this hypothesis are not currently available. There is a need to characterise immune re- sponses among children and adults exposed to infection for the first time. Such studies may help identify the determinants of the age-related susceptibility/resistance to primary infection by $P$. falciparum.

The hypothesis of age-dependent immunity includes definition of susceptibility and resistance in terms of age of the host and the conditions of exposure (i.e. acute or chronic). The predicted trends will undoubtedly deviate, especially at the very extremes of age. This is an especially important consideration with neonatal humans, who bear the brunt of malaria-attributable mortality. Extrapolation of the trends hypothesised here to neonates may not be appropriate. For all age-groups, direct experimental evidence is needed to test the hypothesis of age-related immunity.

\section{CONCLUSIONS}

A T-cell-dependent shift from susceptibility to resistance during normal ageing has been demonstrated in mice and rats. Epidemiological studies of humans exposed to chronic malaria also show age-dependent differences in the rate of acquisition of natural immu-

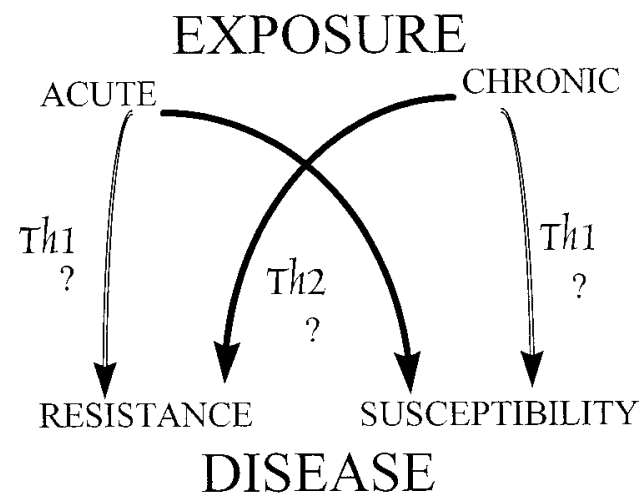

Fig. 9. Paradigm for age-dependent, T-cell immune responses to acute or chronic infection with $P$. falciparum, driving protection or exacerbation of disease. The hollow arrows denote immune responses from children (Th1) and the solid arrows denote those from adults (Th2). 
TABLE 2

Mouse-Plasmodium systems affecting the prima ry response to challenge with blood-stage parasites, and the outcomes of the infections

\begin{tabular}{lcccl}
\hline Parasite & Host & Primary response & Outcome & Reference \\
\hline$P$. yoelii 17XL & C57BL/6 & Th2 & Death & Shear et al. (1990) \\
$P$. yoelii 17XNL & C57BL/6 & Th1 and Th2 & Recovery & Kobayashi et al. (1996) \\
$P$. berghei ANKA & C57BL/6 & Th2 & Death & Weidanz and Grun (1983) \\
$P$. c. chabaudi & A /J & Th2 & Death & Jacobs et al. (1995) \\
$P$. c. chabaudi & C57BL/6 & Th1 to Th2 & Recovery & Langhorne (1989) \\
$P$. c. adami & C57BL/6 & Th1 & Recovery & Taylor-Robinson (1995) \\
\hline
\end{tabular}

nity. Whether the susceptibility to disease in children under chronic exposure to infection is related to dominance of the immune response by naive $\mathrm{T}$ cells remains to be seen. Likewise, attribution of the relative resistance in chronically exposed adults to a predominantly memory-T-cell response remains speculative. Further studies to collect data on the Th1- $v$. Th2-like nature of the responses of chronically exposed humans would help resolve the questions. Such data is even more urgently needed to begin to understand the age-related susceptibility of humans to primary exposure to infection.

An age-dependent immunity to $P$. falciparum governed by the degree of recent exposure and Th1- v. Th2-dominated responsiveness would have important implications in the field of vaccine development. The separate requirements for vaccines for the individual and for those for the community have been discussed elsewhere (Hoffman and Miller, 1995). In brief, a vaccine for the individual should prevent acute malaria in the non-immune traveller (primarily adults), whereas a vaccine for the community should target disease among the chronically exposed (primarily children). These distinct objectives may not only produce differing criteria for successful clinical and field testing, but may also create the need for entirely separate strategies for development. For example, a vaccine that induces Th1-type responses may be the ideal for individuals, especially adults, whereas an inducer of Th2type response may prove most helpful for an endemic community, especially for the children. The induction of adult-like immunity in children would prove enormously beneficial in areas such as sub-Saharan Africa (see Fig. 1). In contrast, a vaccine inducing a Th2-like response may be poorly suited for the traveller, as would one inducing a Th1like response in the chronically exposed (Fig. 6 ). The potential for manipulating immune responses to vaccines in the direction of Th1or Th2-like T-cell subpopulations has been described (Golding et al., 1994).

The practice of taking vaccines from phase-IIa trials in non-immune adults to phase-IIb trials in chronically exposed children may frustrate successful development. A vaccine that establishes protection in nonimmune adults may not do so in chronically exposed children. Perhaps more importantly, vaccine candidates that fail early clinical trials in non-immune adults may effectively protect chronically exposed children from disease and death. Vaccines intended for the prevention of mortality in children may not successfully pass through immunogenicity and efficacy trials in non-immune adults.

ACKNOWLEDGEMENTS. The author is grateful to S. Hoffman, M. James, J. Langhorne, D. Doolan, W. Rogers and T. Jones for their thoughtful advice on this manuscript. The views of the author are his own and do not purport to represent those of the U.S. Navy or the Department of Defense. This work was supported by the U.S. Naval Medical Research and Development Command (work unit STO F 6.3A-250). 


\section{REFERENCES}

Aguiar, J. C., Albrecht, G. R., Cegielski, P., Greenwood, B. M., Jensen, J. B., Lallinger, G., Martinez, A., MCGregor, I. A., Minjas, J. N. \& Neequaye, J. (1992). Agglutination of Plasmodium falciparum-infected erythrocytes from East and West African isolates by human sera from distant geographic regions. American Journal of Tropical Medicine and Hygiene, 47, 621-632.

Alger, N. E., Branton, M., Harant, J., Willis, L. \& Silverman, P. H. (1972). Plasmodium berghei NK65 in the inbred A/J mouse: age immunity in the female retired breeder A/J mouse. Journal of Protozoology, 19, 511-515.

andersen, E. M., Jones, T. R., Purnomo, Masbar, S., Wiady, I., Tirtokusumo, S., Bangs, M. J., Charoenvit, Y., Gunawan, S. \& Hoffman, S. L. (1997). Assessment of age-dependent immunity to malaria in transmigrants. American Journal of Tropical Medicine and Hygiene, 56, 647-649.

Antonaci, S., Poligano, A., Tortorella, C., Garofalo, A. R., Jirillo, E. \& Bonomo, L. (1992). Role of interleukin 2, interleukin 4 , and interleukin 5 in the $\mathrm{T}$ helper cell-driven $\mathrm{B}$ cell polyclonal differentiation in the elderly. Cytobios, 70, 77-85.

Atmosoedjono, S. (1990). Malaria control in Indonesia since World War II. Wageningen Agricultural University Papers, 90-7, 141-154.

BAIRD, J. K. (1995). Host age as a determinant of naturally acquired immunity to Plasmodium falciparum. Parasitology Today, 11, 105-111.

Baird, J. K., Jones, T. R., Danudirgo, E. W., Annis, B. A., Bangs, M. J., Basri, H., Purnomo \& Masbar, S. (1991). Age-dependent acquired protection against Plasmodium falciparum in people having two years exposure to hyperendemic malaria. America n Journal of Tropical Medicine and Hygiene, 45, 65-76.

Baird, J. K., Purnomo, Basri, H., Bangs, M. J., Andersen, E. M., Jones, T. R., Masbar, S., Harjosuwarno, S., Subianto, B. \& ARbani, P. R. (1993). Age-specific prevalence of Pla smodium falciparum among six populations with limited histories of exposure to endemic malaria. American Journal of Tropical Medicine and Hygiene, 49, 707-719.

Baird, J. K., Sismadi, P., Masbar, S., Ramzan, A., Purnomo, B. W., Sekartuti, Tjitra, E., Rumoko, B. W. \& ARbani, P. R. (1996). A focus of endemic malaria in central Java. American Journal of Tropical Medicine and Hygiene, 54, 98-104.

Baird, J. K., Masbar, S., Basri, H., Tirtokusumo, S. \& Hoffman, S. L. (1998). Adult susceptibility to epidemic falciparum malaria. Journal of Infectious Diseases, in press.

Bastien, P. (1987). Particularités épidémiologiques des accès pernicieux à Plasmodium falciparum dan un contexe d'épidémie palustre. Vanuatu, 1975-1985. Médecine Tropicale, 47, 125-131.

BEVERLY, P. C. L. (1994). Human T cell repertoire, heterogeneity and memory: relevance to malaria. Immunology Letters, 41, 121-122.

BINING, N. \& MILLER, R. A. (1997). Cytokine production by subsets of CD4 memory cells differing in P-glycoprotein expression; effects of aging. Journals of Gerontology, Series A, 52, B137-B145.

Binka, F. N., MORris, S., Ross, D., ARThur, P. \& ARYEetey, M. (1994). Patterns of malaria morbidity and mortality in children in northern Ghana. Transactions of the Royal Society of Tropical Medicine and Hygiene, 88, 381-385.

Binka, F. N., MAUde, G., Gyapong, M., Ross, D. \& SMith, P. (1995). Risk factors for child mortality in northern Ghana: a case-control study. International Journal of Epidemiology, 24, 127-135.

Boтtomly, K. (1988). A functional dichotomy in CD4 + T lymphocytes. Immunology Today, 9, 195-197.

Boudin, C., Sheick, I., Chumpitazi, B., Pazart, L., Hogh, B., Peyron, F., Deloron, P., Picot, S. \& AMBroISE-ThOmas, P. (1994). The multifactorial and multistage character of protective immunity to Plasmodium falciparum, naturally acquired by an indigenous population in Burkina Faso. Scandina vian Journal of Immunology, 39, 409-417.

Bouharoun-Tayoun, H. \& Druilhe, P. (1992). Pla smodium falciparum malaria: evidence for an isotype imbalance which may be responsible for delayed acquisition of protective immunity. Infection and Immunity, 60, 1473-1481.

BOYD, E. (1932). The weight of the thymus gland in health and in disease. American Journal of Disea ses of Children, 43, 1162.

Briere, F., Servet-Delprat, C., Bridon, J. M., Saint-Remy, J. M. \& Banchereau, J. (1994). Human interleukin 10 induces naive surface immunoglobulin $\mathrm{D}+(\mathrm{sIgD}+) \mathrm{B}$ cells to secrete $\operatorname{IgG} 1$ and $\operatorname{IgG} 3$. Journal of Experimental Medicine, 179, 757-762. 
BROWN, K. N. \& BROWN, I. N. (1965). Immunity to malaria: antigenic variation in chronic infections of Plasmodium knowlesi. Nature, 208, 1286-1288.

Bruce-Chwatt, L. J. (1952). Malaria in African infants and children in southern Nigeria. Annals of Tropical Medicine and Parasitology, 46, 173-200.

Bryan, J. H. \& SMalley, M. E. (1978). The use of A-B-O blood group markers for mosquito biting studies. Transactions of the Royal Society of Tropical Medicine and Hygiene, 72, 357-360.

Buchanan, J. M., Vogel, L. A., van Cleave, V. H. \& Metzger, D. W. (1995). Interleukin 12 alters the isotype-restricted antibody response of mice to hen eggwhite lysozyme. International Immunology, 7 , $1519-1528$

Buck, R. A. \& Eichenlaub, D. (1994). Prognostiche faktoren der malaria tropica-ergebnisse einer evaluationsstudie in der Bundesrepublik Deutschland 1963-1988. Gesundheitsw esen, 56, 29-32.

Budd, R. C., Cerottini, J. C., Horvath, C., Bron, T., Pedraazzini, T., Howe, R. C. \& Macdonald, H. R. (1987). Distinction of virgin and memory T lymphocytes: stable acquisition of the Pgp-1 glycoprotein concomitant with antigenic stimulation. Journal of Immunology, 138, 3120-3125.

Burkot, T. R., Graves, P. M., Paru, R. \& Lagog, M. (1988). Mixed blood feeding by the malaria vectors in the Anopheles punctulatus complex. Journal of Medical Entomology, 25, 205-213.

CHRISTOPHERS, S. R. (1924). The mechanism of immunity against malaria in communities living under hyperendemic conditions. Indian Journal of Medical Research, 12, 273-294.

Ciuca, M., Ballif, L. \& Chelarescu-Vieru, M. (1934). Immunity in malaria. Transactions of the Royal Society of Tropical Medicine and Hygiene, 27, 619-622.

CLARKE, I. A. (1983). Correlation between susceptibility to malaria and babesia parasites and to endotoxicity. Transactions of the Royal Society of Tropical Medicine and Hygiene, 76, 4-7.

Coggeshall, L. (1938). Plasmodium lophurae, a new species pathogenic for domestic fowl. American Journal of Hygiene, 27, 615-618.

Curtin, P. D. (1994). Malarial immunities in nineteenth century West Africa and Caribbean. Parassitologia, 36, 69-82.

Desowitz, R. S. (1989). Plasmodium-specific immunoglobulin E in sera from an area of holoendemic malaria. Transactions of the Royal Society of Tropical Medicine and Hygiene, 83, 478-479.

Desowitz, R. S., Elm, J. \& Alpers, M. P. (1993). Pla smodium falciparum-specific immunoglobulin G ( $\operatorname{IgG})$. IgM, and $\operatorname{IgE}$ antibodies in paired maternal cord sera from East Sepik province, Papua New Guinea. Infection and Immunity, 61, 988-993.

Dick, S., Waterfall, J. C., MADDy, A. \& Riley, E. (1996). Naive human alpha beta T cells respond to membrane-associated components of malaria-infected erythrocytes by proliferation and production of gamma interferon. Immunology, 88, 412-420.

D'imperio-Lima, M. R., Alvarez, J. M., Furtado, G. C., Kipnis, T. L., Coutinho, A. \& Minoprio, P. (1996). Ig-isotype patterns of primary and secondary B cell responses to Pla smodium chabaudi chabaudi correlate with IFN-gamma and IL-4 cytokine production with CD45RB expression by CD4 + spleen cells. Scandinavian Journal of Immunology, 43, 263-270.

DORIA, G. \& FrASCA, D. (1994). Ageing and genetic control of immune responsiveness. Immunology Letters, 40, 231-233.

Egan, A. F., Chappel, J. A., Burghaus, P. A., Morris, J. S., McBride, J. S., Holder, A. A., Kaslow, D. C. \& RILEY, E. M. (1995). Serum antibodies from malaria-exposed people recognize conserved epitopes formed by the two epidermal growth factor motifs of MSP119, the carboxy-terminal fragment of the major merozoite surface protein of Plasmodium falcipa rum. Infection and Immunity, 63, $456-466$.

EHLERS, S. \& SMITH, K. A. (1991). Differentiation of T cell lymphokine gene expression: the in vitro acquisition of $\mathrm{T}$ cell memory. Journal of Experimental Medicine, 173, 25-36.

EL Demellawy, M. \& EL RIDI, R. (1992). Age-associated decrease in proportion and antigen expression of $\mathrm{CD} 8^{+} / \mathrm{CD}^{+}{ }^{+}$thymocytes in BALB/c mice. Mechanisms of Ageing and Development, 62, 307-318.

Elghazali, G., Esposito, F. \& Troye-Blomberg, M. (1995). Comparison of the number if IL-4 and IFN-gamma secreting cells in response to the malaria vaccine candidate antigen Pf155/RESA in two groups of naturally primed individuals living in a malaria endemic area in Burkina Faso. Scandinavian Journal of Immunology, 42, 39-45.

Ernst, D. N., Hobbs, M. V., Torbett, B. E., Galsebrook, A. L., Rehse, M. A., Bottomly, K., Hardy, R. R. \& Weigle, W. O. (1990). Differences in the expression profiles of CD45RB, Pgp-1, and 3G11 
membrane antigens and in the pattern of lymphokine secretion by splenic CD $4+$ cells from young and aged mice. Journal of Immunology, 145, 1295-1302.

Ernst, D. N., Weigle, W. O., Noonan, D. J., McQuitTy, D. N. \& Hobbs, M. V. (1993a). The age-associated increase in IFN-gamma synthesis by mouse CD $8+\mathrm{T}$ cells correlates with shifts in the frequencies of cell subsets defined by membrane CD44, CD45RB, 3G11, and MEL-14 expression. Journal of Immunology, 151, 575-587.

Ersnt, D. N., Weigle, W. O. \& Hobbs, M. V. (1993b). Aging and lymphokine production by T cell subsets. Stem Cells, 11, 487-498.

Frasca, D., Pucci, S., Goso, C., Barattini, P., Barile, S., Pioli, C. \& Doria, G. (1997). Regulation of cytokine production in aging: use of recombinant cytokines to upregulate mitogen-stimulated spleen cells. Mechanisms of Ageing and Development, 93, 157-169.

GILL, C. A. (1914). Epidemic or fulminant malaria together with a preliminary study of the part played by immunity to malaria. Indian Journal of Medical Research, 2, 268-315.

GILL, C. A. (1936). Some points in the epidemiology of malaria arising out of the study of the malaria epidemic in Ceylon in 1934-35. Transactions of the Royal Society of Tropical Medicine and Hygiene, 29, 429-480.

Golding, B., Zaitseva, M. \& Golding, H. (1994). The potential for recruiting immune responses toward type 1 or type $2 \mathrm{~T}$ cell help. American Journal of Tropical Medicine and Hygiene, 33 (Suppl. 4), 33-40.

GOOD, M. F. (1991). The implications for malaria vaccine programs if memory T cells from non-exposed humans can respond to malaria antigens. Current Opinion in Immunology, 3, 496-502.

Good, M. F. (1995). Development of immunity to malaria may not be an entirely active process. Parasite Immunology, 17, 55-59.

Good, M. F., QUAKYI, I. A., Berzofsky, J. A., CARTER, R. \& Miller, L. H. (1987). Human T cell clones reactive to the sexual stages of Pla smodium falciparum malaria: high frequency of gamete-reactive $\mathrm{T}$ cells in peripheral blood from nonexposed donors. Journal of Immunology, 138, 306-311.

Greenberg, A. E. \& Lobel, H. O. (1990). Mortality from Pla smodium falcipa rum malaria in travelers from the United States, 1959 to 1987. Annals of Internal Medicine, 113, 326-327.

GregoreK, H., IMielska, D., Gornicki, J., Mikolajewicz, J. \& MADAlinski, K. (1994). Development of IgG subclasses in healthy Polish children. Archivum Immunoligae et Therapiae Experimentalis, 42, $377-382$.

Hara, H., Negoro, S., Miyata, S., Saiki, O., Yoshizaki, K., Tanaka, T., igarashi, T. \& Kishimoto, S. (1987). Age-associated changes in proliferative and differentiative response of human B cells and production of T cell-derived factors regulating B cell functions. Mechanisms of Ageing and Development, 38, 245-258.

HaYAKaWA, K. \& HARDY, R. R. (1989). Phenotypic and functional alteration of CD4 + cells after antigen stimulation: resolution of two populations of memory cells that both secrete interleukin-4. Journal of Experimental Medicine, 169, 2245-2248.

HIROKAWA, K. (1977). The thymus and aging. In Immunology and Aging, eds Makinodan, T. \& Yunis, E. pp. 51-72. New York: Plenum.

Hirokawa, K., Utsuyama, M., Kasai, M. \& Kurashima, C. (1992). Aging and immunity. Acta Pathologica Japonica, 42, 537-548.

Hirokawa, K., UtsuYama, M. \& KaSAi, M. (1994). Understanding the mechanism of the age-change of thymic function to promote $\mathrm{T}$ cell differentiation. Immunology Letters, 40, 269-277.

Hobbs, M. V., Weigle, W. O., NoOnan, D. J., TORbett, B. E., MCEVilly, R. J., Koch, R. J., Cardenas, G. J. \& ERNST, D. N. (1993). Patterns of cytokine gene expression by CD4 + T cells from young and old mice. Journal of Immunology, 150, 3602-3614.

Hoffman, S. L. \& Miller, L. H. (1996). Perspectives on malaria vaccine development. In Malaria Vaccine Development: a Multi-immune Response Approach, ed. Hoffman, S. L. pp. 1-13. Washington, DC: American Society for Microbiology.

Hommel, M., David, P. H. \& Oligino, L. (1983). Surface alterations of erythrocytes in Plasmodium falcipa rum malaria: antigenic variation, antigenic diversity, and the role of the spleen. Journal of Experimental Medicine, 157, 1137-1148.

IWAShima, M., Nakayama, T., KUbo, M., ASAno, Y. \& TADa, T. (1987). Responses of T cells from aged and chimeric mice. International Archives of Allergy and Applied Immunology, 83, 129-137.

Jacobs, P., Radzioch, D. \& Stevenson, M. M. (1995). Nitric oxide expression in the spleen, but not the liver, correlates with resistance to blood stage malaria in mice. Journal of Immunology, 155, 5306-5313. 
Jones, K. R., Hickling, J. K., Targett, G. A. \& Playfair, H. L. (1990). Polyclonal in vitro proliferative responses from nonimmune donors to Plasmodium falciparum malaria antigens require UCHL1 + (memory) T cells. European Journal of Immunology, 20, 307-315.

Jones, T. R., Baird, J. K., Bangs, M. J., Annis, B. A., Purnomo, Basri, H., Gunawan, S., Harjosuwarno, S., MCElroy, P. D. \& Hoffman, S. L. (1994). Malaria vaccine study site in Irian Jaya, Indonesia: Plasmodium falciparum incidence measurements and epidemiologic considerations in sample size estimation. American Journal of Tropical Medicine and Hygiene, 50, 210-218.

KARIV, I., FERguson, F. G. \& CONFER, F. L. (1992). Age- and strain-related differences in murine spleen cell responses to different activation signals. Cellular Immunology, 140, 67-80.

KASPER, L. H. \& ALGER, N. E. (1973). Adoptive transfer of immunity to Plasmodium berghei by spleen and lymph node cells from young to old mice. Journal of Protozoology, 20, 445-449.

KAWANO, Y. \& NOMA, T. (1996). Role of interleukin-2 and interferon-gamma in inducing production of IgG subclasses in lymphocytes of human newborns. Immunology, 88, 40-48.

KAWANO, Y., NOMA, T. \& YATA, J. (1994). Regulation of human IgG subclass production by cytokines. IFN-gamma and IL-6 act antagonistically in the induction of IgG1 but additively in the induction of IgG2. Journal of Immunology, 153, 4948-4958.

Kawano, Y., Noma, T., Kou, K., Yoshizawa, I. \& Yata, J. (1995). Regulation of human IgG subclass production by cytokines: human IgG subclass production enhanced differentially by interleukin-6. Immunology, 84, 278-284.

Kishimoto, S., Tomino, S., Kotegawa, S., Sato, T., Kuroki, M., Mitsuya, M. \& Hisamitsu, M. (1978). Age-related changes in the subset and function of human T lymphocytes. Journal of Immunology, 121, $1773-1780$

Kobayashi, F., Morit, T., Masui, T., Fujino, T., Watanabe, Y., Weidanz, W. P. \& Tsuji, M. (1996). Production of interleukin 10 during malaria caused by lethal and nonlethal variants of Pla smodium yoelii yoelii. Parasitology Research, 82, 385-391.

KOCH, R. (1900a). Zweiter bericht über die thatigkeit der malaria-expedition. Deutsche Medizinische Wochenschrift, 26, 88-90.

KOCH, R. (1900b). Dritter bericht über die thatigkeit der malaria-expedition. Deutsche Medizinische Wochenschrift, 26, 296-297.

KOCH, R. (1900c). Vierter bericht über die thatigkeit der malaria-expedition. Deutsche Medizinische Wochenschrift, 26, 397-398.

KOCH, R. (1900d). Fünfter bericht über die thatigkeit der malaria-expedition. Deutsche Medizinische Wochenschrift, 26, 541-542.

LEE, W. T. \& VITETTA, E. S. (1991). The differential expresion of homing and adhesion molecules on virgin and memory $\mathrm{T}$ cells in the mouse. Cellular Immunology, 132, 215-219.

LEE, W. T., Yin, X. M. \& ViteTta, E. S. (1990). Functional and ontogenic analysis of murine CD45Rhi and CD45Rlo CD4 + T cells. Journal of Immunology, 144, 3288-3292.

Langhorne, J. (1989). The role of CD4 $+\mathrm{T}$ cells in the immune response to Plasmodium chabaudi. Parasitology Today, 5, 362-365.

Lepers, J. P., Deloron, P., Andriamagatiana-Rason, M. D., Ramanamirija, J. A. \& Coulanges, P. (1990). Newly transmitted Plasmodium falciparum malaria in the central highland plateaux of Madagascar: assessment of clinical impact in a rural community. Bulletin of the World Health Organization, 68, 217-222.

Lewis, V. M., Twomey, J. J., Bealmear, P., Goldstein, G. \& Good, R. A. (1978). Age, thymic involution, and circulating thymic hormone activity. Journal of Endocrinology and Metabolism, 47, 145-150.

LORENZ, M., JUNG, S. \& RADBRUCH, A. (1995). How cytokines control immunoglobulin class switching. Behring Institute Mitteilungen, 96, 97-102.

LuCEY, D. R., Clerici, M. \& SHEArer, G. M. (1996). Type 1 and Type 2 cytokine dysregulation in human infectious, neoplastic and inflammatory diseases. Clinical Microbiology Reviews, 9, 532-562.

MakinOdan, T. \& KAY, M. M. B. (1980). Age influence on the immune system. Advances in Immunology, 29, 287-330.

MakinOdan, T., Chang, M., NORman, D. C. \& LI, S. (1987). Vulnerability of the T-cell lineage to aging. In Aging and the Immune Response-Cellular and Humoral Aspects, ed. Goidl, E. A. pp. 27-43. New York: Marcel Dekker.

MARSH, K. \& HOWARD, R. J. (1985). Antigens induced on erythrocytes by $P$. falcipa rum: expression of diverse and conserved determinants. Science, 231, 150-152. 
MCBRIDE, J. S., WALliker, D. \& MORGAN, G. (1982). Antigenic diversity in the human malaria parasite Plasmodium falciparum. Science, 217, 254-257.

MCGregor, I. A. (1993). Towards a vaccine against malaria. British Journal of Biomedical Science, 50, $35-42$.

MCGREGOR, I. A. \& SMITH, D. A. (1952). A health, nutrition and parasitological survey in a rural village (Keneba) in West Kiang, Gambia. Transactions of the Royal Society of Tropical Medicine and Hygiene, 46, 403-427.

Mosmann, T. R. \& SAD, S. (1996). The expanding universe of T-cell subsets: Th1, Th2 and more. Immunology Today, 17, 138-146.

Mshana, R. N., Boulandi, J., MShana, N. M., Mayombo, J. \& Mendome, G. (1991). Cytokines in the pathogenesis of malaria: levels of IL-1beta, IL-4, IL-6, TNF-alpha, and interferon gamma in the plasma of healthy individuals and malaria patients in a holoendemic area. Journal of Clinical and Laboratory Immunology, 34, 131-139.

Murasko, D. M., Weiner, P. \& KaYe, D. (1987). Decline in mitogen induced proliferation of lymphocytes with increasing age. Clinical and Experimental Immunology, 70, 440-448.

Nagel, J. E., Chrest, F. J. \& ADler, W. H. (1981). Enumeration of T lymphocyte subsets by monoclonal antibodies in young and aged humans. Journal of Immunology, 127, 2086-2089.

Newbold, C. I., Pinches, R., Roberts, D. J. \& MArsh, K. (1992). Plasmodium falciparum: the human agglutinating antibody response to the infected red cell surface is predominantly variant specific. Experimental Parasitology, 75, 281-292.

ORTEga-MORA, L. M. \& WRight, S. E. (1994). Age-related resistance in ovine cryptosporidiosis: patterns of infection and humoral immune response. Infection and Immunity, 62, 5003-5009.

Pahlavani, M. A. \& Richardson, A. (1996). The effect of age on the expression of interleukin-2. Mechanisms of Ageing and Development, 89, 125-154.

Perlmann, H., Helmby, H., Hagstedt, M., Carlson, J., Larsson, P. H., Troye-Blomberg, M. \& Perlmann, P. (1994). IgE elevation and IgE anti-malarial antibodies in Plasmodium falciparum malaria: association of high IgE levels with cerebral malaria. Clinical and Experimental Immunology, 97, 284-292.

Port, G. R., Boreham, P. F. L. \& Bryan, J. H. (1980). The relationship of host size to feeding by mosquitoes of the Anopheles gambiae complex. Bulletin of Entomological Research, 70, 133-144.

Powers, D. C. (1994). Effect of age on serum immunoglobulin G subclass antibody responses to inactivated influenza virus vaccine. Journal of Medical Virology, 43, 57-61.

RAfFale, G. \& BALDi, A. (1950). Sulla morfologia e sulla transmission di P. berghei. Rivista Malariologia, 29, 341-347.

RAZANAmparany, M. S., RANDriamiharisoa, F. S., RZANamparany, N. J. D. \& Ramialimanana, V. (1995). L'épidémie de paludisme à Antananarivo de 1983 à 1994 vue à travers le Service de Pediatrie A de l'Hôpital General de Befelatanana. Cahiers Santé, 5, 382-385.

Riley, E. M., Jakobsen, P. H., Allen, S. J., Wheeler, J. G., Bennett, S. \& Greenwood, B. M. (1991). Immune response to soluble exoantigens of Plasmodium falciparum may contribute to both pathogenesis and protection in clinical malaria: evidence from a longitudinal prospective study of semi-immune African children. European Journal of Immunology, 21, 1019-1025.

Riley, E. M., Morris-Jones, S., Blackman, M. J., Greenwood, B. M. \& Holder, A. A. (1992). Naturally acquired cellular and humoral immune responses to the major merozoite surface protein (MSP1) of Plasmodium falciparum are associated with reduced malaria morbidity. Parasite Immunology, 14, 321-327.

Romagnani, S. (1996). Th1 and Th2 in human diseases. Clinical Immunology and Immunopa thology, 80, $225-235$.

RZEPCZyK, C., Hale, K., Woodroffe, N., Bobogare, A., CSurhes, P., IShit, A. \& Ferrante, A. (1997). Humoral immune responses of Solomon Islanders to the merozoite surface antigen 2 of Plasmodium falciparum show pronounced skewing towards antibodies of the immunoglobulin 3 subclass. Infection and Immunity, 65, 1098-1100.

Sabcharoen, A., Burnouf, T., Ouattara D., Attanath, P., Bouharoun-Tayoun, H., ChantaVanich, P., Foucault, C., Chongsuphajaisiddhi, T. \& Druilhe, P. (1991). Parasitologic and clinical human response to immunoglobin administration in falciparum malaria. American Journal of Tropical Medicine and Hygiene, 45, 297-308. 
SAnders, M. D., MAKGOBa, M. W. \& SHAW, S. (1988). Human naive and memory T cells: reinterpretation of helper-inducer and sup-pressor-inducer subsets. Immunology Today, 9, 195-198.

Sarthou, J.-L., Angel, G., Aribot, G., Rogier, C., Dieye, A., Balde, A. T., Diatta, B., Seignot, P. \& Roussilhon, C. (1997). Prognostic value of anti Plasmodium falciparum-specific immunoglobulin G3, cytokines, and their soluble receptors in West African patients with severe malaria. Infection and Immunity, 65, 3271-3276.

SChÜFfner, W. A. P. (1919). Two subjects relating to the epidemiology of malaria. Mededeelingen van der Burgerlijken Geneeskundigen Dienst in Nederlandsch-Indie, 9, 1-34.

Seder, R. A., Gazzinelli, A., Sher, A. \& Paul, W. E. (1993). IL-12 acts directly on CD4 + T cells to enhance priming for IFN gamma production and diminishes IL-4 inhibition of such priming. Proceedings of the National Academy of Sciences of the United States of America, 90, 10 188-10 190.

SHEAR, H. L., NG, C. \& ZHAO, Y. (1990). Cytokine production in lethal and non-lethal murine malaria. Immunology Letters, 25, 123-127.

Shi, Y. P., Sayed, U., Qari, S. H., Roberts, J. M., Udhayakumar, V., Oloo, A. J., Hawley, W. A., Kaslow, D. C., Nahlen, B. L. \& Lal, A. A. (1996). Natural immune response to the C-terminal 19-kilodalton domain of Plasmodium falciparum merozoite surface protein 1. Infection and Immunity, 64, 2716-2723.

Singer, I., HADField, R. \& LAKONEN, M. (1955). The influence of age on the intensity of infection with Plasmodium berghei in the rat. Journal of Infectious Diseases, 97, 15-21.

SOME, E. S. (1994). Effects and control of highland malaria epidemic in Uasin Gishu district, Kenya. East African Medical Journal, 71, 2-8.

SONi, P. N. \& Gouws, E. (1996). Severe and complicated malaria in Natal/KwaZulu. South African Medical Journal, 86, 653-656.

Spira, D. T., Silverman, P. H. \& Gaines, C. (1970). Anti-thymocyte serum effects on Pla smodium berghei infection in rats. Immunology, 19, 759-766.

Swain, S. L., Weinberg, A. D., English, M. \& Huston, G. (1990). IL-4 directs the development of Th2-like helper effectors. Journal of Immunology, 145, 3796-3799.

Taylor, R. R., Smith, D. B., Robinson, V. J., McBride, J. S. \& Riley, E. M. (1995). Human antibody response to Plasmodium falciparum merozoite surface protein 2 is serogroup specific and predominantly of the immunoglobulin G3 subclass. Infection and Immunity, 63, 4382-4388.

TAYlOR-Robinson, A. W. (1995). Regulation of immunity to malaria: valuable lessons learned from murine models. Parasitology Today, 11, 334-342.

Thoman, M. L. \& Weigle, W. O. (1989). The cellular and subcellular bases of immunosenescence. Advances in Immunology, 46, 221-261.

TRAGER, W . \& MCGHEE, R. B. (1950). Factors in plasma concerned with natural resistance to avian malaria parasite (Plasmodium lophurae). Journal of Experimental Medicine, 91, 365-379.

Troye-Blomberg, M., Riley, E. M., Kabilan, L., Holmberg, M., Perlmann, H., Andersson, U., Heusser, C. H. \& Perlmann, P. (1990). Production by activated human T cells of the interleukin 4 but not interferon gamma is associated with elevated levels of serum antibodies to activating malaria antigens. Proceedings of the National Academy of Sciences of the United States of America, 87, 5484-5486.

Troye-Blomberg, M., Berzins, K. \& Perlmann, P. (1994). T-cell control of immunity to the asexual blood stages of the malaria parasite. Critical Reviews in Immunology, 14, 131-155.

Utsuyama, M., Kasai, M., Kurashima, C. \& Hirokawa, K. (1991). Age influence on the thymic capacity to promote differentiation of $\mathrm{T}$ cells: induction of different composition of $\mathrm{T}$ cell subsets by aging thymus. Mechanisms of Ageing and Development, 58, 267-277.

Utsuyama, M., Hirokawa, K., Kurashima, C., Fukayama, M., inamatsu, T., Suzuki, K., Hashimoto, W. \& SATO, K. (1992). Differential age-change in the numbers of CD4 + CD45RA + and CD4 + CD29 + T cell subsets in human peripheral blood. Mechanisms of Ageing and Development, 63, $57-68$.

Van Cleave, V., Wolf, S., Murray, K., Wiencis, A., Ketchum, M., Bliss, J., Haire, T., Resmini, C., MAYLOR, R. \& ALDERMAN, E. (1995). Immunoglobulin isotype modulation after administration of IL-12. Advances in Experimental Biology and Medicine, 383, 43-52.

VIE, H. \& Miller, R. A. (1986). Decline, with age, in the proportion of mouse T cells that express IL-2 receptor after mitogen stimulation. Mechanisms of Ageing and Development, 33, 313-322. 
WEIDANZ, W. P. \& GRUN, J. L. (1983). Antibody-independent mechanisms in the development of acquired immunity to malaria. Advances in Experimental Biology and Medicine, 162, 409-423.

WeKsler, M. E. (1994). Immune senescence. Annals of Neurology, 35, S35-S37.

WERnSDORFER, G. \& WERNSDORFER, W. H. (1988). Social and economic aspects of malaria and its control. In Malaria: Principles and Practice of Malariology, eds Wernsdorfer, W. H. \& McGregor, I. pp. 1421-1471. Edinburgh: Churchill Livingstone.

Wilson, D. B. (1936). Rural hyper-endemic malaria in Tanganyika Territory. Transactions of the Royal Society of Tropical Medicine and Hygiene, 29, 583-617.

Yachie, A., Konno, A., OHta, K., Wada, T., Seki, H., Taniguchi, N. \& MiYawaki, T. (1995). Delineation of producing ability of IgG and IgA subclasses by naive B cells in newborn infants and adult individuals. Clinical and Experimental Immunology, 102, 204-209.

ZuCKerman, A. \& Yoeli, M. (1953). Age and sex as factors influencing Plasmodium berghei infections in intact and splenectomized rats. Journal of Infectious Disea ses, 94, 225-236. 